\title{
The Use of Indicator Species and Ecological Degradation Model for Rangeland Condition Assessment in Turkey
}

\author{
*Sabahaddin ÜNAL'1 , Bilal ȘAHIN³ , Öztekin URLA², Berna EFE² \\ ${ }^{1}$ Abant İzzet Baysal University, Faculty of Agricultural and Natural Sciences, \\ Field Crops Department Gölköy, Bolu \\ ${ }^{2}$ Central Field Crop Research Institute, Șehit Cem Ersever Cad. No: 9-11, Yenimahalle, Ankara \\ ${ }^{3}$ Yapraklı Vocational High School, Çankııı Karatekin University, Çankııı, Turkey \\ *Sorumlu yazar e-posta (Corresponding author; e-mail): sabahaddin04@yahoo.com
}

Geliș Tarihi (Received): 14.09.2017～Kabul Tarihi (Accepted): 28.11.2017

\begin{abstract}
Monitoring of vegetation change is essential to detect good management practices for the sustainable use of natural rangeland resources. An understanding of how the existing species in vegetation react to management methods is important for decision makers. For this reason, the vegetation changes should be determined by suitable techniques. The multivariate analysis as Detrended Correspondence Analysis and Principal Components Analysis was highly examined and its results were easily interpreted to draw conclusions. A relatively homogenous data set first, a matrix of 221 species and 44 sample sites in the province of Yozgat in the Central Anatolia Region in year 2010, was used by detrended correspondence analysis (DCA). The effects of environmental variation was minimized by this method (DCA) so that the major pattern of vegetation composition change was explained by grazing impact. Principal components analysis was performed to detect the distribution of sites along the first axis, and the distance off the $x$-axis. Fifteen species out of the promising 89 plant species were found to be indicators. These indicator species should be benefited for the vegetation change status and sustainable rangeland management under semiarid rangeland conditions. The fifteen plant species and bare ground showed clear responses along the first axis (grazing impact gradient), and became abundant over certain ranges of this axis.
\end{abstract}

Keywords: Monitoring, grazing impact, ecological model, sustainable rangeland management.

\section{Türkiye'de Mera Durum Değerlendirmesi için İndikatör Tür ve Ekolojik Bozulma Modeli Kullanımı}

\section{Öz}

Doğal mera kaynaklarının sürdürülebilir kullanımında iyi mera yönetim uygulamalarının belirlenmesi için vejetasyon değișiminin izlenmesi hayati bir önemdedir. Vejetasyondaki her bir türün, en azından yaygın bulunan türlerin, amenajman uygulamalarına nasıl tepki verdiğini anlama, karar vericiler için mükemmel bir araçtır. Bunun için vejetasyon değișiminin değerlendirilmesinde Doğrusal Olmayan Ana Bileșenler Analizi ve Ana Bileșenler Analizi gibi çoklu değișken analizleri oldukça faydalıdır. 2010 yılında ilk olarak Orta Anadolu Bölgesinde Yozgat iline ait 44 örnek durakta saptanan ve 221 tür içeren veri matriksinde Doğrusal Olmayan Ana Bileșenler Analizi kullanılmıștır. Bu metod ile çevresel değișim etkileri minimize edilmiș ve böylece vejetasyon değișim kompozisyonunun ana yapısı otlatma etkisiyle açıklanmıștır. Birinci eksen boyunca durakların dağıımının ve bu eksene uzak durakların belirlenmesi için PCA kullanıımıștır. Birinci eksen (otlatma etki ekseni) boyunca 15 bitki türü ve boș alan açık bir tepki gösterdi ve bu eksenin belirli bölgelerinde yoğunlașma meydana geldi. Bitki türlerinden ümitvar 89 bitki türünden yalnı 15 bitki türü indikatör olarak bulunmuștur. Bu indikatör türler yarı kurak mera șartlarında mera değișim durumu ve sürdürülebilir mera yönetimi için kullanılabilir.

Anahtar Kelimeler: İzleme, otlatma etkisi, ekolojik model, sürdürülebilir mera yönetimi. 


\section{Introduction}

$\mathrm{T}$ he range monitoring studies are mainly focus on describing and detecting the best management techniques which include range improvement and maintenance methods. Monitoring and assessing of present status are therefore integral parts of the best or the sustainable range management. Numerous trials have been accomplished for achieving these objectives so that the useful approaches were adopted such as models, assumptions, and hypothesizes.

The recent development of the research on range ecosystem are based on using the two important tools of monitoring and assessing practices (Hurt and Bosch 1991; Gibson and Bosch 1996; Herrick et al. 2006).

Monitoring gives us opportunities as decision making and range wide new knowledge (Gibson et al. 1995). De Soyza et al. (2000) expressed that vegetation change of rangelands is an even earlier indicator of the potential for ecosystem change and deterioration which are ascribed to combinations of environmental (e.g. recurrent drought) and anthropogenic factors such as over-grazing and mismanagement of rangelands.

The vegetation change is closely linked to the management practices and its history. Hence the rangeland resource status should be repeatedly monitored over time. The main significant subjects in monitoring programs are mentioned following as being fast and sensitive to vegetation change, the trend identification, and the evaluation of sustainable management implementations, respectively. Jacobo et al. (2006) emphasized that the impact of grazing on community structure and ecosystem functioning is a key issue for range management in order to maximize livestock production and sustainability of the operations.

Many studies were completed on plant response to grazing and determination of indicators (Wilson et al. 1988; Tamzen et al. 2003; Bashari 2006; Unal et al. 2013). Many vegetation scientists (Smith, 1988; Bosch, 1989; Wikeem and Pitt 1991; Tamzen etal. 2003) have recently improved the understanding of vegetation change in the world grassland, and interpreted some of the changes within a historical framework of rangeland use (Smith, 1988; Jameson, 1988; Friedel, 1991; Laycock, 1991; David et al. 2002; Bestelmeyer and Herrick 2004; Herrick et al. 2006). Early works included the observations of Cockayne (1920), Connor (1964), and Connor and Macrae (1969) on the response of species to grazing intensities in grasslands (Gibson and Bosch 1996; Oztas et al. 2003).

The modern condition assessment techniques need quantitative relationships of how species react to environmental and management factors, especially to grazing impact (Gibson and Bosch 1996). These relationships can be used for vegetation change, and serve as a basis for the objective condition assessment and interpretation of vegetation monitoring data (Bosch and Gauch 1991). Smith (1988), and Del Giorgio et al. (1991) pointed out that multivariate analysis has been used to assess impacts on site and habitat scales directly by analyzing temporal and spatial patterns (Cao et al. 2001).

The ordination techniques are highly beneficial to describe (ter Braak 1987; Jameson 1988; Fuhlendorf and Smeins 1997; Bashari 2006; Zemmrich 2007; Pietzsch 2008) and realize (Smith 1988; Jameson 1988; FernandezGimenez and Allen-Diaz 2001; Bashari 2006) the grazing impact gradient through data representing differences in composition of plant species especially induced by grazing.

Plant species and indicator species were variously assessed and interpreted by vegetation scientists for their ideas and reviews. For examples, Inam-ur-Rahim and Maselli (2004) pointed out that indicators play a fundamental role in sustainable development as pointers to reveal conditions and trends in development, and to guide users and planners in making decisions about rangeland use. In additionally, van der Westhuizen et al. (2005) said that indicator species are used for rangeland condition assessment. Moreover, Inam-ur-Rahim and Maselli (2004) defined indicators that are likely to be sufficiently widespread or common to have potential in spatially or environmentally disparate locations. 
The main objective of this study was to understand the vegetation dynamics of a particular study area and determine how individual species respond to grazing impact with using multivariate approaches to identify vegetation changes and indicators. Another objective of that was to develop an ecological degradation model (EDM) for the vegetation of a particular study area by (1) reviewing the literature to draft an EDM (2) using multivariate techniques to validate the model (3) incorporating the knowledge of scientists and land managers into the model to refine and obtain a broad opinion about the model.

\section{Methods}

\section{Study Area}

The survey area, Yozgat county, is placed in the Central Anatolia Region. The study sites elevations range between $825 \mathrm{~m}$ and $1680 \mathrm{~m}$, latitude and longitude are between 39.080$40.240(N)$ and 34.150-35.98 (E), respectively.

The region, which has a rough topography, is described by steppe climatic status. Long term and annual (2010 year) mean of precipitation, and temperature were as follows: $603 \mathrm{~mm}$ and $723 \mathrm{~mm} ; 8.9^{\circ} \mathrm{C}$ and $11.3^{\circ} \mathrm{C}$, respectively (GDSMS 2010).

The slopes of the study area are generally changeable and range from flat to steep slopes with uneven appearance.

The soil samples were analyzed for standard soil properties (CSFWRRI 2010).

Brown soils are common in the area with severe erosion. Soils are shallow in the study area with soil textures range from loam to clayloam. It is slightly alkaline and neutral with lime values of soil samples changing from low level to high level. Although phosphorus amount of soils are low and very low level, potassium content is in high level and soils are generally low in organic matter.

\section{Sampling}

Studied sites were finely chosen for representing on vegetation changes of Yozgat province. Each sites were visited with Global Positioning Systems (GPS) device and one site was worked in there (Figure 1). Field work was conducted between May and June 2010.
The plant basal area of existing species on rangeland vegetation and bare ground were identified through Wheel Point Method with Loop (Koç ve Çakal 2004) at the fixed sites.

Two transect lines of $100 \mathrm{~m}$ long in each sites were sampled with an interval of 0.5 meter, so that the 200 reading points were recorded on each transect line (total 400 points).

Plant covering areas were figured out and found total covering area, then the percentages of species were calculated in the sites.

The studied 44 sites were in the indigenous vegetation of grassland in Yozgat Province.

A relatively homogeneous grazing area (RHGA), in which field work was performed, is defined as similar habitat factors. These sites were unimproved and no fertilizer or seed were applied.

The total rangeland-meadow area is 260 153 ha with 198004 livestock units (LUs) in the Province (PAED 2011). Mean carrying capacity (MCC) in the rangelands is quantified as 34 687 LU. Present livestock units are much more 5.7 times than MCC of those rangelands.

Plant samples were properly picked up and dried up for making herbarium. They all were detected by related flora books as Davis 1965-1985, Davis 1988, Güner et al 2000. Moreover, habitat features and grazing impacts (eye estimation method as no grazing 1 , slightly grazing 2 , intermediate grazing 3 , intensity grazing 4 , high intensity grazing 5 ) with soil properties and erosion status, soil compactness were registered for each site.

\section{Data analysis \\ Ordination Analysis}

During the vegetation survey, 221 plant species were found in 44 sites of Yozgat province. All data collected were processed step by step as follows.

All vegetation data converted into cepformat, then they were controlled through pre-check software program named compose program (Bosch 2009). After that the compose program was operated, and the numbers 


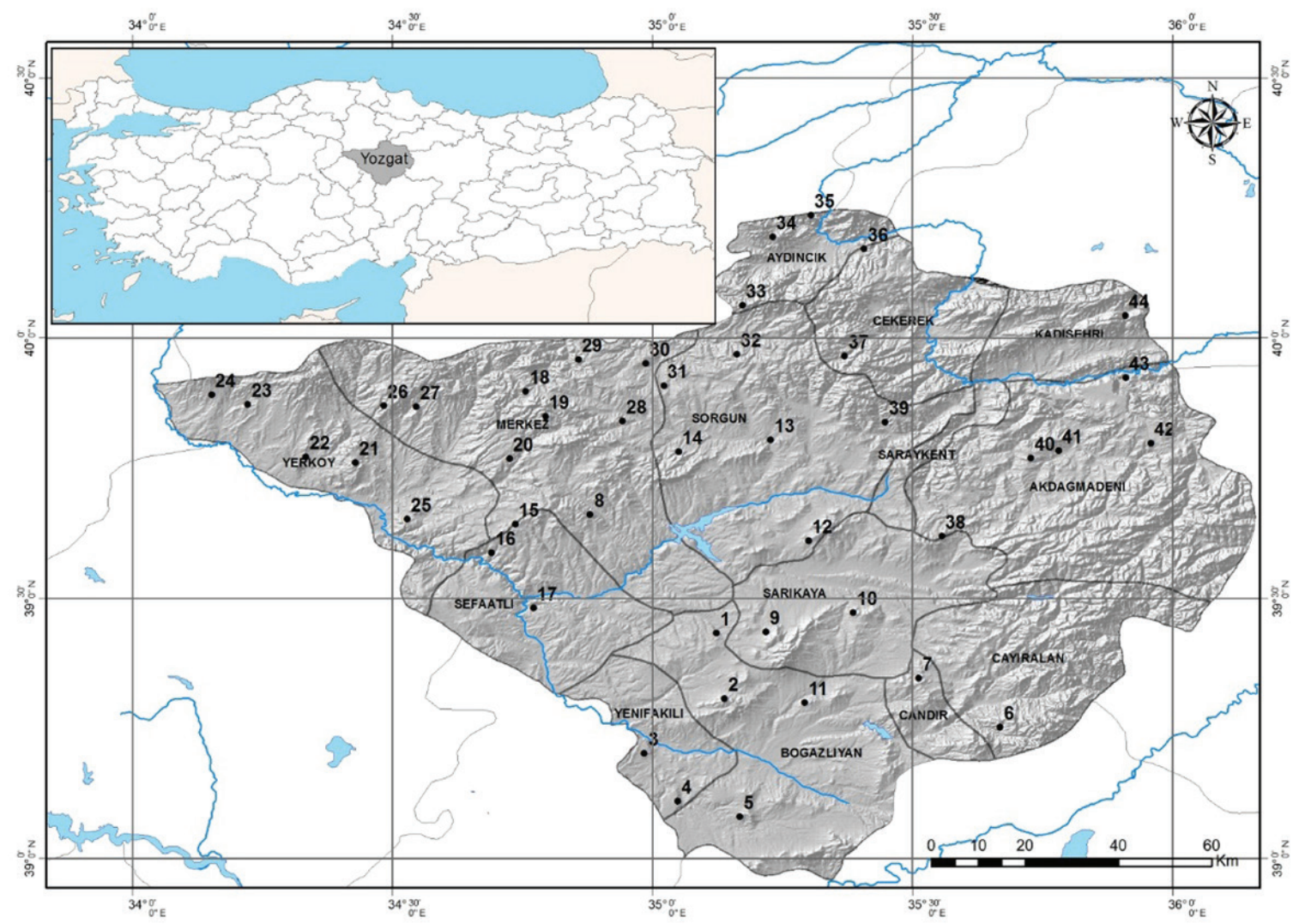

Figure 1. Study sites on the county map of Yozgat. Șekil 1. Yozgat il haritasında çalıșma durakları.

of plant species were decreased to 89 by elimination of some rare species.

Species that occurred on less than $10 \%$ of the sample sites were considered rare, and were removed from the data set to refrain introducing unnecessary data (Mentis 1983).

Moreover, all vegetation survey data was entered into software package program named the Integrated System for Plant Dynamics (ISPD) for the analyzing of ordination (Bosch et al. 1992). After that two ordination techniques such as detrended correspondence analysis (DCA) and principal component analysis (PCA) were performed in that software program.

The first step in the analysis was to identify possible relative homogeneous vegetation groups. For this reason, Detrended Correspondence Analysis (DCA) (Hill and Gauch 1980) was used for ordinating the data matrix. This technique was recommended by Gauch (1982) for the analysis of data sets with high sample heterogeneity, and reported by Hill and Gauch (1980) as superior to a number of other ordination techniques for the analysis of a variety of complex field and simulated data sets.

At the second step, the distribution of various habitat factors on the ordination was found and handled as a basis to identify relatively homogeneous vegetation. Sites (if any) identified as being significantly different from any of these data groups (i. e. outliers) were removed because their relationship to other samples in the data set wasn't expressed by information in the data. This might also cause problems for the ordination (Gauch 1982).

A modification to the sample centered PCA analysis was used to combine the second and higher axes into a single residual value, which provided a measure for each site of its distance off the first axis (Bosch and Gauch 1991). The PCA ordination was inspected to ensure that no sample sites had residuals larger than $50 \%$ of the Euclidean distance of the first ordination axis. Any sample sites exceeding this were not considered to fit the ordination 
model adequately. These sample sites were then discarded and the ordination was done again (Bosch and Kellner 1991; Bosch and Gauch 1991). In addition, the positions of samples along the first axis were correlated on Pearson's product-moment correlation coefficient (Sokal and Rolf 1981) for the indices of inferred accumulated grazing intensity, as well as with other habitat variables.

\section{Indicator Species Identification and Classification}

The first axis represented a grazing intensity gradient for each study site, the percentage covers of species were placed along the first axis. Species, especially possible indicators, that showed a possible correlation with the grazing impact gradient were recorded. Regression analyses on these species were performed after fitting a Gaussian (Normal) distribution curve. Although real ecological response curves were often more complex, Gaussian models were useful in describing data showing mostly unimodal responses and were generally accepted (ter Braak and Prentice 1988; Palmer 1993). The usefulness of the Gaussian response was confirmed in numerous direct gradient studies, and had become the basis for testing and designing multivariate models (Gauch 1982).

The D Statistic (Willmott 1982) or "index of agreement" was used to determine how well the recorded data fitted the relationship with the first axis (Bosch and Kellner 1991; Bosch and Gauch 1991).

Indicator species were classed into response groups on the basis of the strength and nature of their relationship with the pastoral impact gradient. Three broad categories were selected to identify with which part of the pastoral impact gradient an indicator species was mostly associated. These three categories conform with those suggested by Hurt et al. (1993), i. e., decreasers, increasers and invaders, following the pioneering concepts of Dyksterhuis (1949).

Constructing of the ecological degradation model

The ecological degradation model was made by based on the cover areas of plant species and bare ground (Figure 2 and Figure 3 ).
The indicator values of the regression analysis were first manually noted down on graphic paper and then the values of the $x$-axis and the $y$-axis were read from the sketch graphic paper. Later, these values were utilized to make an ecological degradation model (Bosch and Gauch 1991) (Figure 3). This model consists of composition on $y$-axis and utilization levels on $\mathrm{x}$-axis.

Degradation increases from left to right along the ordination gradient, which is related to bare ground cover and unpalatable species. Meanwhile the cover area of perennial palatable plant species reduces from left side to right side along $x$ axis. Range condition classes such as good, fair, poor-deteriorated, and poor-degraded have the rate of decreasers and increasers on composition with 10-20\% and $33-50 \% ; 5-10 \%$ and $14-23 \% ; 5-8 \%$ and $10-15 \% ; 2-5 \%$ and $0-10 \%$, respectively in the ecological graph model.

\section{Results and Discussions \\ Ordination techniques}

Accordingtotheresults of the DCAordination technique, a relatively homogeneous area was detected throughout 44 sites which had similar ecological aspects. Then the centered PCA ordination was performed with the sample sites by species matrix of new dataset. All sites were placed along degradation gradient by means of deterioration levels.

\section{Indicator species identification}

Of the 221 species were found during the surveys, 89 species remained after applied compose program, and finally 45 species were detected as possible indicators.

The analyses of regression resulted fifteen plant species and bare ground. A_d-statistic value as over 0.3 referred the continuing grazing severity (Table 1). Each plant species was individually analyzed for abundance and regression in order. After regression analysis, results were carefully checked and some plant species were selected as indicators which have the values of $r^{2}$ and $D$ higher than 0.300 (Table 1 and Figure 2).

The ecological classifications of species, based upon response to grazing, were classified 

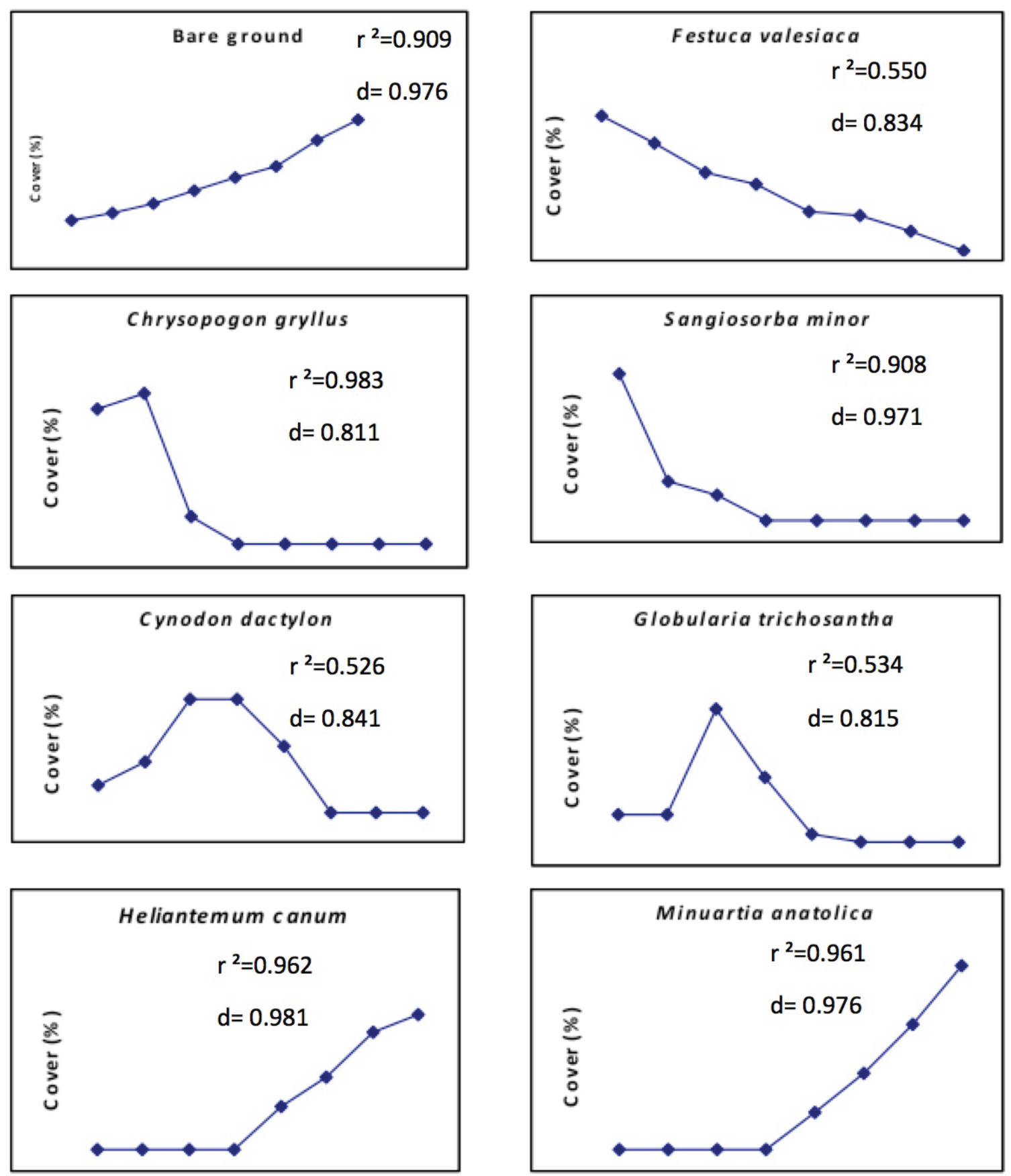

Grazing intensity

Figure 2. The values of $r^{2}$ and $d$ statistics of indicator species. Șekil 2. Indikator türlerinin $r^{2}$ ve $d$ istatistik değerleri.

as decreasers, increasers, and invaders in plant species coverage (Dyksterhuis 1949).

The fifteeen species (six decreasers, three increasers, and six invaders) out of all plant species (221 species) on botanical composition were identified as indicators for rangeland vegetations in Yozgat Province.

\section{Indicators for good and fair range conditions}

Decreaser plant species result in a good range condition. But they are extremely influenced negatively under the over grazing pressure. These highly palatable plants decline in increasing of grazing pressure (Dyksterhuis 1949; Hurt et al. 1993; Koç et al. 2003; Holechek 


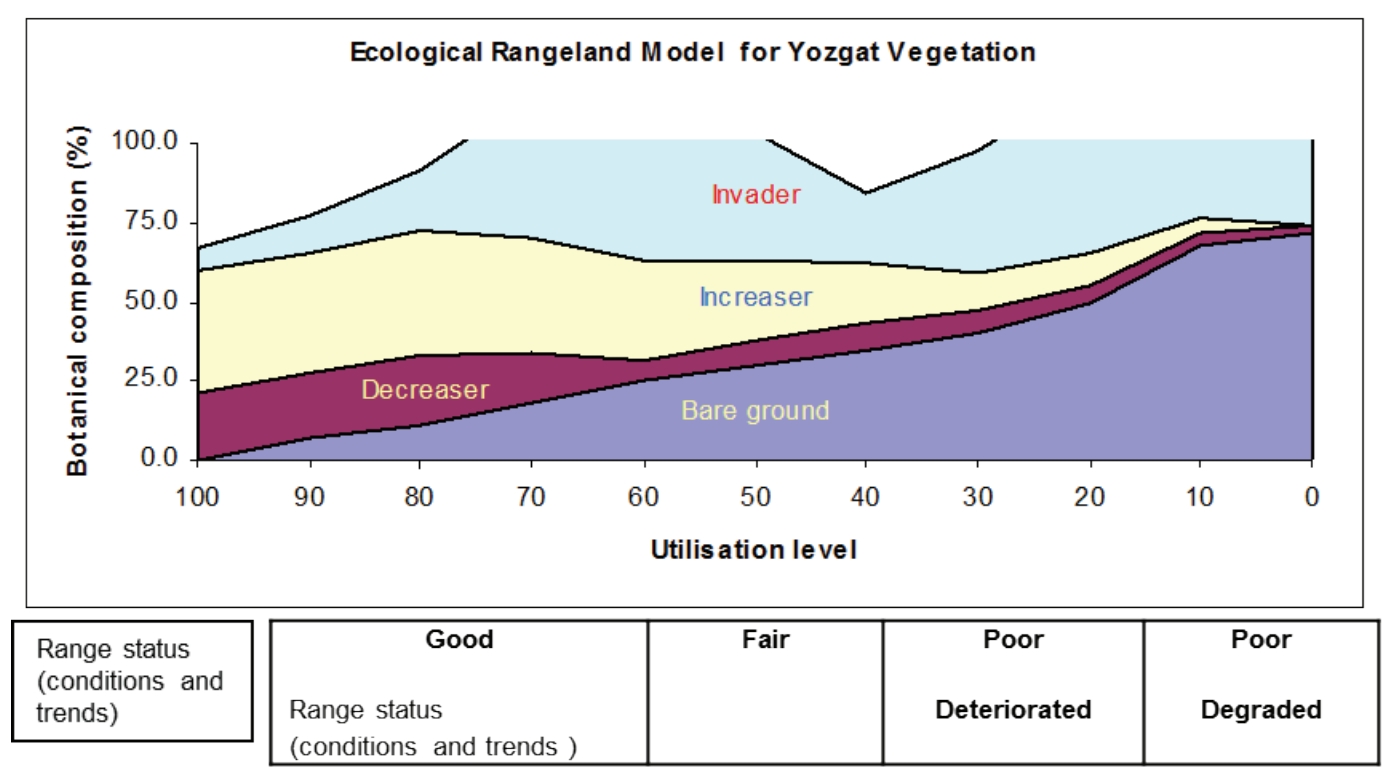

Figure 3. The graph of ecological degradation model without bare ground, and explanations of range condition and trend.

Șekil 3. Boș alan olmadan ekolojik bozulma modeli grafiği ve mera durum ve eğiliminin açıklanmaları.

et al. 2004; David 2011). The six decreaser plant species of the rangeland in the Yozgat Province were determined as indicators, three grass species such as downy brome (Bromus tomentellus), scented grass (Chrysopogon gryllus), orchardgrass (Dactylis glomerata), two decreaser legumes such as variegated alfalfa (Medicago varia), and sainfoin (Onobrychis oxydonta) and one from other family, Rosaceae, small burnet (Sangiosorba minor). In this study, three increaser species, two grasses and one species from Globulariaceae family, were identified. Two grasses were as following; Volga fescue (Festuca valesiaca) and bermuda grass (Cynodon dactylon). The one species from other family was blue globe daisy (Globularia trichosantha).

Survey results obviously indicated that the following species are indicators for good rangeland condition; Bromus tomentellus, Chrysopogon gryllus, Dactylis glomerata, Medicago varia, Onobrychis oxyodonta, Sangiosorba minor, Festuca valesiaca, Cynodon dactylon, and Globularia trichosantha.

Overgrazing of rangeland always causes to reduce or remove desirable perennial plants in vegetation and as a result of this reason range condition declines (David 2011; Ünal et al.
2013). The same authors added information for opposite status that there existed an increase in the density of desirable perennial plants may be indicated a recovery in range condition.

Increaser plant species, which may increase slightly or remain stable under moderate grazing, are classified as increaser types that are moderately palatable and uncommon in the climax vegetation. As grazing pressure increases or as range condition declines fair condition, these species also decline on plant community (Dyksterhuis 1949; Hurt et al. 1993; Holechek et al. 2004).

\section{Indicators for poor condition}

The six invader species in this study were found as indicators for the range sites having poor (deteriorated and degraded) range condition score which are Alyssium pateri $\left(\mathrm{r}^{2}=\right.$ $0.868, d=0.948$ ), yellow chamomile (Anthemis tinctori), Phlomis armeniaca, Sulphur cinquefoil (Potentilla recta), Hoary rockrose (Heliantemum canum), and Stitchwort (Minuartia anatolica).

Invaders are generally unpalatable, but they decrease or increase related to utilization level through final stages of deterioration (Dyksterhuis 1949; Hurt et al. 1993; Holechek et al. 2004). These plant species are completely accepted as being undesirable plants that are typically 
Table 1. The values of $r^{2}$ and $d$ statistics of some indicator species and bare ground.

Çizelge 1. Boș alan ve bazı indikator türlerinin $r^{2}$ ve $d$ istatistik değerleri.

\begin{tabular}{|c|c|c|c|c|c|c|c|}
\hline & Bare ground and plant species & r 2 & $d$ & & Plant species & r 2 & $d$ \\
\hline 1 & Bare ground & 0.909 & 0.976 & 24 & Erodium ciconium & 0.945 & 0.979 \\
\hline 2 & Achillea biebersteinii & 0.550 & 0.840 & 25 & Festuca valesiaca & 0.550 & 0.834 \\
\hline 3 & Aegilops umbelliata & 0.900 & 0.972 & 26 & Fumana procumbens & 0.473 & 0.798 \\
\hline 4 & Alyssum condensatum & 0.993 & 0.998 & 27 & Genista sessifolia & 0.603 & 0.870 \\
\hline 5 & Alyssum pateri & 0.868 & 0.948 & 28 & Globularia trichosantha & 0.534 & 0.815 \\
\hline 6 & Anthemis tinctoria & 0.922 & 0.975 & 29 & Helianthemum canum & 0.962 & 0.981 \\
\hline 7 & Asphodeline taurica & 0.856 & 0.948 & 30 & Helianthemum ledifolium & 0.929 & 0.959 \\
\hline 8 & Astragalus plumosus & 0.960 & 0.982 & 31 & Marrubium parviflorum & 0.976 & 0.989 \\
\hline 9 & Astragalus tigridis & 0.792 & 0.942 & 32 & Medicago minima & 0.644 & 0.886 \\
\hline 10 & Bromus tomentellus & 1.000 & 0.391 & 33 & Medicago sativa & 0.855 & 0.938 \\
\hline 11 & Centaurea pichleri & 0.732 & 0.923 & 34 & Minuartia anatolica & 0.961 & 0.976 \\
\hline 12 & Centaurea solstiitalis & 0.306 & 0.693 & 35 & Minuartia hybrida & 0.574 & 0.850 \\
\hline 13 & Centaurea urvillei & 0.830 & 0.924 & 36 & Noaea mucronata & 0.333 & 0.713 \\
\hline 14 & Chardinia orientalis & 0.412 & 0.797 & 37 & Onobrychis oxydanto & 0.346 & 0.701 \\
\hline 15 & Chrysopogon gryllus & 0.483 & 0.811 & 38 & Phlomis armeniaca & 0.727 & 0.912 \\
\hline 16 & Convolvulus holosericeus & 0.998 & 0.999 & 39 & Potentilla recta & 0.929 & 0.981 \\
\hline 17 & Convolvulus lineatus & 0.812 & 0.917 & 40 & Prangos meliocarpoides & 0.908 & 0.976 \\
\hline 18 & Cousinia stapfiana & 0.638 & 0.885 & 41 & Salvia crypthantha & 0.995 & 0.997 \\
\hline 19 & Cynodon dactylon & 0.526 & 0.841 & 42 & Sangiosorba minor & 0.908 & 0.971 \\
\hline 20 & Dactlis glomerata & 0.996 & 0.999 & 43 & Taraxacum scaturiginosum & 0.985 & 0.981 \\
\hline 21 & Dianthus zonathus & 0.980 & 0.995 & 44 & Trachynia distachya & 0.998 & 0.999 \\
\hline 22 & Euphorbia macroclada & 0.393 & 0.787 & 45 & Verbascum cheiranthifolium & 0.549 & 0.856 \\
\hline 23 & Ebenus laguroides & 0.983 & 0.986 & & & & \\
\hline
\end{tabular}

Bold written species $=$ selected indicator species

Koyu yazılanlar = seçilmiș indikator türler

of limited value for grazing (David 2011). For this reason, grazing systems and grazing plans must be applied for controlling undesirable plant species increase on rangeland vegetation. Otherwise, their increase may cause decline in range condition (David 2011).

Invaders are generally unpalatable, and their abundance increase as overgrazing continues (Dyksterhuis 1949; Hurt et al. 1993; Holechek et al. 2004). These plant species are completely accepted as being undesirable plants that are typically of limited value to grazing (David 2011).

For the rangeland management, the occurrence of invader plant species is not required in vegetation, but they are vital significant for maintenance soil under the continuing soil erosion in the steppe rangelands (Koç et al. 2000).

\section{Bare ground}

In addition to other indicator species bare ground, an environmental variable, is also determined as an indicator having the statistical parameters of $r^{2}=0.909$ and $d=$ 0.976. Bare ground is also an important additional parameter for evaluating real changes in rangeland condition (Abulea et al. 2007).

Changes (especially increase in this study) in bare ground cover are highly based on grazing pressure and management techniques (continuous grazing, uncontrolled grazing etc.) (Figure 2). Moreover, bare ground cover represents rangeland health and it is one of the important criteria for interpretation and assessment of rangeland present status.

According to study results, bare ground cover increases, therefore, rangeland health 
deteriorates. High grazing intensity leads to reduce palatable species in botanical composition.

Bare ground is a good indication of overutilization or livestock pressure, and a degree of the degradation of the vegetation (Abulea et al. 2007). Fernandez et al. (2013) observed a clear relationship between livestock density and bare soil surface cover. They found that bare ground was very high in the rangelands sites in which high grazing density existed.

Conversely, while vegetation cover increases, rangeland health improves due to reducing soil erosion, high biomass yield, and improving vegetation composition with increasing palatable species area. Moreover, plant cover reduces directly negative impact of raindrops so it employs to be the best defense against soil erosion. The decrease in soil canopy coverage is a result of severity of erosion due to overgrazing (Oztas et al. 2003).

Pellant et al. (2005) cited by various authors that the amount and distribution of bare ground is one of the most important contributors to site stability relative to the site potential; therefore, it is a direct indication of site susceptibility to accelerated wind or water erosion. Bare ground, a qualitative and quantitative indicator, is positively correlated with canopy gaps, runoff and erosion (David et al. 2002). Another significant viewpoint on the use of bare ground as a quantitative indicator which would provide better precision in determining rangeland trend may be monitored and followed the trend of rangeland status over time (David et al. 2002). The assessment of rangeland health was based upon erosion, plant vigor and biodiversity (Koc et al. 2003). Moreover they focused on rangeland health having productivity and sustainability of plant community on soil cover. Erosion problems occurs $80 \%$ of the world's rangelands (Thurow 1991) and Turkey's rangeland ecosystems are most susceptible against erosion impact (Koc et al. 2000). Therefore, rangeland health is much more priority than rangeland condition. Under the prevailing conditions of soil erosion on rangelands, it is impossible to be claimed as healthy for rangeland of Yozgat.

If excessive livestock regularly removes threshold amounts of biomass and litter, a degradation spiral is started especially in heavily used areas (Teague et al. 2011). Moreover, first this progressive deterioration is explained by replacement of taller perennial grasses by shorter perennial grasses. Then annual grasses and forbs are dominant and finally bare ground widely appears (Thurow 1991; Fuls 1992; O'Connor 1992; Ash and Stafford-Smith 1996; Teague et al. 2004). Bare ground or soil may be chosen as an indicator of animal utilization.

\section{Ecological degradation model}

The ecological degradation model is also based upon survey, and multivariate statistical analysis, moreover making graph (Figure 3). Jameson (1988) explained three various models for management of rangeland ecosystems as follows (1) the statistical analyses of model-based monitoring systems, (2) model-based analyses for determining optimal management strategies, and (3) system attributes that dictate model structure. This study model fits first and second models of his three descriptions above. Furthermore, models were also categorized into research guidance models, systems behavior models and management oriented models by the same author. On this point, Rajabov (2009) also proposed a model which was based on current knowledge and available field data, and seemed to correspond to the system behavior, as suggested by Non Metric Multidimensional Scaling ordination. It hence appears to reflect the dynamics of the study area as vegetation change, land degradation, grazing intensity, current management regime etc.

In this study, the ecological degradation model was made and presented in Figure 3 , which gives an overall assessment and interpretation relevant current status of Province rangelands.

There are two main components covering composition (\%) and utilization level on the graph. As observed figure 3 , the four various rangeland status were that consists of range conditions such as good (from 65 to 100), fair (from 39 to 64), poor-deteriorated (from 21 to 38 ), and poor-degraded (from 0 to 20) in utilization levels along $x$ axis. 
Composition (\%) on y axis contains the cover rates of bare ground, decreasers, increasers, and invaders in botanical composition. They all are the most important indicators for assessment and interpretation of rangelands status and trend. Bare ground rates vary from 0 , 19,38 , and 45 to $18,37,44$, and 60 at the good, fair, poor-deteriorated, and poor-degraded rangelands, respectively.

Range condition classes such as good, fair, poor-deteriorated, and poor-degraded have the rates of decreasers and increasers on composition with $10-20 \%$ and $33-50 \%$; $5-10 \%$ and $14-23 \% ; 5-8 \%$ and $10-15 \%$; $2-5 \%$ and $0-10 \%$, respectively. As observed in Figure 3, the cover area of perennial palatable plant species reduces from left side to right side along $x$ axis. Palatable species cover decrease during deteriorating and degrading of rangelands. This means that rangelands become poor, and degraded so they have the increased bare ground cover and invader species. As a results, less productivity, high erosion, and environmental harm may occur on these rangeland areas. Moreover, palatable species have given way to unpalatable species, and signs of land degradation were apparent where the most intensive grazing has taken place (Rajabov 2009). In addition, application of such ecological concepts in range assessment helps to understand the driving factors of vegetation changes and to provide a framework for solution of degradation problems and sustainable management of natural resources (Rajabov 2009).

\section{Conclusion}

Fifteen species were identified as the indicators for monitoring and following on vegetation changes in the grasslands of Yozgat Province. These fifteen species showed range condition trend because of being more sensitive to grazing intensity than to other environmental factors, which makes them useful in providing an early mark of changes in the rangeland ecological system. The indicator species are used to monitor vegetation condition which is significant process for both production and conservation of rangelands through informing and warning rangeland managers to significant changes within range ecosystem. The assessment and interpretation of vegetation condition will give benefit information on current management practices, new measures to be taken if needed. The study area has been misused with different level of grazing intensity by now. It means that there haven't been applied any improvement and management techniques in all rangeland areas in this province. The indicator species determined for various rangeland conditions are so useful that any changes could be sensitively monitored and followed. This approach can be used to investigate current status of rangelands and also for monitoring the effects of current management techniques. When invaders for indicator of poor rangeland condition are taken precaution to be reduced, the percentages of especially decreasers and increaser also should be tried to increase in vegetation community. Consequently, the effective range management and rehabilitation techniques should be implemented for rehabilitation of these rangeland areas, perhaps it is possible that the present situation can be reversed toward climax condition.

\section{Acknowledgements}

The corresponder author is indebted to Professor Ali Koç (Agricultural Faculty of Eskișehir Osmangazi University) and and Dr. Lütfi Tahtacioğlu (former Director General of the General Directorate of Agricultural Research and Policy) thank for critical review and help. We would like to thank to Professor Taner Akar (Akdeniz University Agricultural Faculty) for comments, and ideas. We're also grateful to all project staff for contributing of field survey. The project was funded by The Scientific and Technological Research of Turkey (TUBITAK), General Directorate of Agricultural Research and Policy (TAGEM), and General Directorate of Crop Production (BUGEM).

\section{References}

Abule E., Snyman H.A., and Smit G.N., 2007. Rangeland evaluation in the middle Awash valley of Ethiopia: I. Herbaceous vegetation cover. Journal of Arid Environments, 70: p. 253271 
Ash A.J., and Stafford Smith M., 1996. Evaluating stocking rate impacts in rangelands: Animals don't practice what we preach. Rangelands Journal 18, 216-43 DOI: 10.1071/RJ9960216

Bashari, H. 2006. Development of processes tools to support the adaptive management in complex rangelands systems. The School of Natural Rural Systems Management, The University of Queensland Gatton (Thesis for the degree of Doctor of Philosophy)

Bestelmeyer B.T., Herrick J.E., Brown J.R., Trujillo D.A., and Havstad K.M., 2004. Land management in the American Southwest: A state-and-transition approach to ecosystem complexity. Environmental Management 34 (1):38-51. DOI: $10.1007 / \mathrm{s} 00267-004-0047-4$

Bosch O.J.H. 1989. Degradation of the semi-arid grasslands of southern Africa. Journal of Arid Environments 16:165-175

Bosch O.J.H., and Gauch H.G., 1991. The use of degradation gradients for the assessment ecological interpretation of rangeland condition. Tydskrif Weidingsveren. S. Afr., 8(4)

Bosch O.J.H., and Kellner K., 1991. The use of a degradation gradients for ecological interpretation of range condition assessments in the western grassland biome of Southern Africa. Journal of Arid Environments 21: 21-29

Bosch O.J.H., Gauch H.R., Booysen J., Stols S.H.E., Gouws G.A., Nel M.W., and Van Zyl E., 1992. ISPD - An Integrated System for Plant Dynamics (Computer Software Package Users Guide). Department of Plant Soil Sciences, Potchefstroom University for Christian Higher Education, Potchefstroom, South Africa. p. 101

Bosch O. 2009. Manual for the use of ISPD and COMPOSE and other notes. Head School of Integrative Systems, The University of Queensland, Australia

Cao Y., Larsen D. P., and Thorne R.St-J., 2001. Rare species in multivariate analysis for bioassessment: some considerations. Journal of the North American Benthological Society 20(1):144-153

Chartier M.P., Rostagno C.M., 2006. Soil erosion thresholds alternative states in Northeastern Patagonian Rangelands. Rangeland Ecology and Management, 59(6):616-624. DOI: 10.2111/06-009R.1

Cockayne L., 1920. An economic investigation of the montane tussock-grassland of New Zealand. IX. Further details regarding the Earnscleugh (Central Otago) palatability experiment. New Zealand Journal of Agriculture 20:324-334

Connor H.E., 1964. Tussock grassland communities in the Mackenzie Country, South Canterbury, New Zealand. New Zeal J Bot 2:325-351

Connor H.E., and MacRae A.H., 1969. Montane subalpine tussock grasslands in Canterbury. In: The Natural History of Canterbury (Ed. GA Knox). Reed, Wellington, New Zealand, pp. 167-204
CSFWRI 2010. Soil analysis results of studied sites of Yozgat province. Central Soil, Fertilizer Water Resources Research Institute, Ankara

Pyke DA., Herrick JE., Shaver P., and Pellant M., 2002. Rangeland health attributes indicators for qualitative assessment. Journal of Range Management 55:584-597

David W., 2011. Rangeland Condition Monitoring (RCM), A Guide For Pastoral Lessees. Department of Agriculture Food, Government of Western Australia, p. 1-31

Davis P.H. (Ed.). 1965-1985. Flora of Turkey the East Aegean Islands, Vols. 1-9, Edinburgh University Press, Edinburgh

Davis P.H., Mill R.R., Tan K., (Eds.) 1988. Flora of Turkey the East Aegean Islands, Vol. 10, (Suppl 1), Edinburgh University Press, Edinburgh

Del Giorgio P.A., Vinocur A.L., Lombardo R.J., and Tell H.G., 1991 Progressive changes in the structure dynamics of the phytoplankton community along a pollution gradient in a lowland river -a multivariate approach. Hydrobiologia 224:129-54

de Soyza A.G., Van Zee J.W., Whitford W.G., Neale A., Tallent-Hallsel N., Herrick J.E., and Havstad K.M., 2000. Indicators of Great Basin rangeland health, Journal of Arid Environments 45(4): 289304. DOI: 10.1006/jare.2000.0645

Dyksterhuis E.J., 1949. Condition management of range land based on quantitative ecology. Journal of Range Management Archives, 2(3): 104-115

FAO, 2012. Vegetation assessment, section 3. Manual for Local Level Assessment of Land Degradation and Sustainable Land Management livelihoods, Field methodology tools, Land Degradation assessment in Drylands (LADA) Project, pp. 40-66

Fernandez-Gimenez M.E., and Allen-Diaz B., 2001. Vegetation change along gradients from water sources in three grazed Mongolian ecosystems. Plant Ecology 157:101-118. DOI: 10.1023/A:1014519206041

Fernández V., Sotiropoulos T., and Brown P., 2013. Foliar Fertilization: Scientific Principles and Field Practices. International Fertilizer Industry Association (IFA), Paris, France

Friedel M.H., 1991. Range condition assessment the concept of thresholds: A viewpoint. Journal of Range Management, 44(5):422-426

Fuhlendorf S.D., and Smeins F.E., 1997. Long-term vegetation dynamics mediated by herbivores, weather and fire in a Juniperus-Quercus savanna. Journal of Vegetation Science 8: 819828, DOI: $10.2307 / 3237026$

Fuls E.R., 1992. Semi-arid arid rangelands: A resource under siege due o patch-selective grazing. Journal of Arid Environments 22(2):191193

Gauch H.G., 1982. Multivariate Analysis in Community Ecology. Cambridge University Press, Cambridge, U.S.A. $298 \mathrm{p}$ 
GDSMS, 2010. The climatic data of Yozgat province. The General Director of State Meteorological Service, Ankara, Turkey

Gee G.W., and Bauder J.W., 1986. Particlesize analysis. Methods of Soil Analysis. Part 1. Physical Mineralogical Methods. 2nd ed. Agronomy 9, Madison, Wisconsin, USA, pp. 383-411

Gibson R.S., and Bosch O.J.H., 1996. Indicator species for the interpretation of vegetation condition in the St Bathans area, Central Otago, New Zealand. New Zealand Journal of Ecology 20(2):163-172

Gibson R.S., Allen W., and Bosch O.J.H., 1995. Condition assessment concepts their role in facilitating sustainable range management. Annals of the Arid Zone 34(3):179-189

Güner A., Özhatay N., Ekim T., and Bașer K.H.C., 2000. Flora of Turkey the East Aegean Islands, (Suppl 2), Vol. 11, Edinburgh University Press, Edinburgh

Herrick J.E., Bestelmeyer B.T., Archer S., Tugel A.J., and Brown J.R., 2006. An integrated framework for science-based arid land management. Journal of Arid Environments 65:319-335 DOI: 10.1016/j.jaridenv.2005.09.003

Hill M.O., and Gauch Jr H.G., 1980. Detrended correspondence analysis: An improved ordination technique. Vegetatio 42(1-3):47-58

Holechek J.L., Pieper R.D., and Herbel C.H., 2004. Range inventory monitoring. Range Management, Principles Practices, 6th ed. pp.186-215

Hurt C.R., and Bosch O.J.H., 1991. The comparison of some range condition assessment techniques used in southern African grasslands. Journal of the Grassland Society of Southern Africa 8:131137

Hurt C.R., Hardy M.B., and Tainton N.M., 1993. Identification of key grass species under grazing in the highland sourveld of Natal. African Journal of Range and Forage Science 10(2):96-102. DOI: 10.1080/10220119.1993.9638331

Maselli D., 2004. Improving Sustainable Grazing Management in Mountain Rangelands of the Hindu Kush-Himalaya, An Innovative Participatory Assessment Method in Northern Pakistan, Mountain Research Development 24( 2):124-133. DOI: 10.1659/0276-4741(2004) 024[0124:ISGMIM]2.0.CO;2

Jacobo E.J., Rodriguez A.M., Bartoloni N., and Deregibus V.A., 2006. Rotational grazing effects on rangeland vegetation at a farm scale. Rangeland Ecology and Management 59:249257. DOI: $10.2111 / 05-129 R 1.1$

Jameson D.A., 1988. Modelling rangeland ecosystems for monitoring adaptive management. In: Tueller P.T. (Ed.), Vegetation science applications for rangeland analysis management, pp.189-224
Koc A., Oztas T., and Tahtacioglu L., 2000. Rangeland-livestock interaction in our near history: problems recommendations. Proceedings of the International Symposium on Desertification, 13-17 June 2000, Konya, Turkey, pp.293-298

Koç A., Gökkuș A., and Altın M., 2003. Comparison of the world-widely used methods in definition of range condition a suggestion for Turkey. Turkey 5. Field Crop Congress, 13-17 October 2003, Diyarbakır. pp.36-42

Koç A., and Çakal Ș., 2004. Comparison of some rangeland canopy coverage methods. Int. Soil Cong. On Natural Resource Manage. For Sust. Develp, June 7-10, 2004, Erzurum, Turkey, D7, 41-45

Laycock W.A., 1991. Stable states thresholds of range condition on North American rangelands: A viewpoint. Journal of Range Management, 44(5):427-433

Marshall J.K., 1973. Drought, land use soil erosion. In: Lovett, J.V. (Ed.), In the Environmental, Economic Social Significance of Drought. Angus Robertson Publ., Inc., London, pp.55-77

Mc Lean E.O., 1982. Soil $\mathrm{pH}$ lime requirement. In: Page A.L. (Ed.), Methods of Soil Analysis. Part 2. Chemical Microbiological Properties. 2nd ed. Agronomy 9, Madison, Wisconsin USA, pp.199224

Mentis M.T., 1983. Towards objective veld condition assessment. Proceedings of the Grassland Society of Southern Africa 18:77-80

Nelson R.E., 1982. Carbonate gypsum. In: Page A.L. (Ed.), Methods of Soil Analysis. Part 2. Chemical Microbiological Properties. 2nd ed. Agronomy 9, Madison, Wisconsin USA, pp.181-197

Nelson D.W., and Sommers L.E., 1982. Total carbon, organic carbon, organic matter. In: Page A.L. (Ed.), Methods of Soil Analysis. Part 2. Chemical Microbiological Properties. 2nd ed. Agronomy 9, Madison, Wisconsin USA, pp.539-579

O'Connor K.F., 1982. The implications of past exploitation current developments to the conservation of South Island tussock grasslands. New Zealand Journal of Ecology 5:97-107

Olsen S.R., and Sommers L.E., 1982. Phosphorus. In: Page A.L. (Ed.), Methods of Soil Analysis. Part 2. Chemical Microbiological Properties. 2nd ed. Agronomy 9, Madison, Wisconsin USA, pp.403-427

Oztas T., Koc A., and Comakli B., 2003. Changes in vegetation soil properties along a slope on overgrazed eroded rangelands. Journal of Arid Environments 55:93-100

PAED, 2011. Agricultural data of Yozgat Province. The Provincial Agriculture Extension Directorates, Yozgat

Palmer M.W., 1993. Putting things in even better order: The advantages of canonical correspondance analysis. Ecology 74(8):22152230 
Pellant M., Patrick S., David A.P., and Herrick J.E., 2005. Interpreting indicators of rangeland health, Technical Reference, 1734-6. United States Department of the Interior Bureau of Land Management National Science Technology Center Division of Science Integration Branch of Publishing Services, P. O. Box 25047Denver, Colorado. www.blm.gov/nstc/library/techref. htm

Pietzsch D., 2008. Vegetation response along grazing gradients in Artemisia-semi-desert of Gobustan (Azerbaijan). Diploma thesis in the study program of Biology at the Ernst Moritz Arndt University, Greifswald

Rajabov T., 2009. Ecological assessment of spatıotemporal changes of vegetation in response to piosphere effects in semi-arid rangelands of Uzbekistan. Land Restoration Training Programme Final Project Keldnaholt, 112 Reykjavík, Iceland

Smith E.L., 1988. Successional concepts in relation to range condition assessment. In: Tueller P.T. (Ed.), Vegetation science applications for rangeland analysis management, pp.113-133

Sokal R.R., and Rolf F.J., 1981. Biometry. San Francisco, USA: W. H. Freeman Company, 859 $p$

Tamzen K.S., Krueger W.C., and Shaver P.L., 2003. State transition modeling: An ecological process approach. Journal of Range Management 56:106-113

Teague W.R., Dowhower S.L., Waggoner J.A., 2004. Drought grazing patch dynamics under different grazing management. Journal of Arid Environments 58:97-117

Teague W.R., Dowhower, S.L., Baker S.A., Haile N., DeLaune P.B., and Conover D.M., 2011. Grazing management impacts on vegetation, soil biota soil chemical, physical hydrological properties in tall grass prairie. Agriculture Ecosystems Environment 141:310-322

Ter Braak C.J.F., 1987. The analysis of vegetationenvironment relationships by canonical correspondence analysis. Vegetatio 69:69-77
Ter Braak C.J.F., and Prentice I.C., 1988. A theory of gradient analysis. Advances in Ecological Research 18:271-317

Thomas G.W., 1982. Exchangeable Cations. In: Page A.L. (Ed.), Methods of Soil Analysis. Part 2. Chemical Microbiological Properties. 2nd ed. Agronomy 9, Madison, Wisconsin USA, pp.159165

Thurow T.L., 1991. Hydrolory erosion. In: Heitschmidt R.K., and Stuth J.W. (Eds.), Grazing management: an ecological perspective. Timber Press, Inc., pp.141-159

Unal S., Mutlu Z., Urla O., Sahin B., and Koc A., 2013. The determination of indicator plant species for steppe rangelans of Nevsehir Province in Turkey. Turkish Journal of Agriculture Forestry, 37(4):401-409. DOI: 10.3906/sag-1205-33

van der Westhuizen H.C., Snyman H.A., and Fouché H.J., 2005. A degradation gradient for the assessment of rangeland condition of a semi-arid sourveld in southern Africa. African Journal of Range and Forage Science, 22(1):4758. DOI: $10.2989 / 10220110509485861$

Wikeem B.M., and Pitt M.D., 1991. Grazing effects range trend assessment on California bighorn sheep range. Journal of Range Management Archives 44(5):446-470

Willmott C.J., 1982. Some comments on the evaluation of model performance. Bulletin of the American Meteorological Society 63(11):13091313

Wilson A.D., Hodgkinson K.C., and Noble J.C., 1988. Vegetation attributes their application to the management of Australian rangelands. In: P.T. Tueller (Ed.), Vegetation science applications for rangeland analysis management, pp.253-294

Zemmrich A., 2006. Vegetation-ecological investigations of rangeland ecosystems in Western Mongolia: the assessment of grazing impact at various spatial scale levels. Greifswald University, Dissertation, 2007. p.132-146 